\title{
Penyuluhan manipulasi fotoperiod pada budidaya ikan patin (Pangasius hypopthalmus) di RW VIII Kelurahan Delima Kecamatan Tampan Pekanbaru
}

\author{
Windarti*, Morina Riauwaty, Henny Syawal, Asmika H Simarmata, \& Isma Mulyani \\ Fakultas Perikanan dan Ilmu Kelautan, Universitas Riau \\ *windarti.unri@gmail.com
}

\begin{abstract}
Abstrak. Kelurahan Delima terletak di kecamatan Tampan Pekanbaru dan memiliki sumberdaya perairan yang memadai. Di kelurahan tersebut terdapat sekolompok ibu-ibu PKK yang sudah pernah melakukan usaha budidaya ikan dalam kolam secara sederhana dan belum menerapkan sistem budidaya ikan yang efektif. Tujuan dari penyuluhan ini adalah untuk memberikan bekal pengetahuan kepada masyarakat agar mampu melakukan usaha budidaya ikan secara sederhana dan ramah lingkungan. Kegiatan "Budidaya ikan dengan manipulasi fotoperiod" dilakukan dengan cara ceramah dengan mengunakan slide dan buku TTG sebagai media ajar. Selain itu juga dilakukan praktek langsung untuk membuat kolam terpal, memelihara ikan patin (Pangasius hypopthalmus) memberi makan, merawat ikan serta mengelola kualitas air pada wadah budidaya ikan. Kegiatan ini dihadiri oleh 25 orang ibu-ibu PKK dari RW VIII. Setelah dilakukan penyuluhan, tingkat pemahaman peserta terhadap materi yang diberikan sekitar $85 \%$. Hasil evaluasi dan monitoring menunjukkan bahwa ibu-ibu PKK di RW VIII tersebut sudah mampu melakukan usaha budidaya ikan dengan manipulasi fotoperiod dengan menggunakan kolam terpal dan kegiatan tersebut dapat berkelanjutan.
\end{abstract}

Kata kunci: kelurahan delima; budidaya ikan; manipulasi fotoperiod; kolam terpal; ikan patin

\begin{abstract}
In the Delima Village, Pekanbaru City, there is a group of women that used to conduct a household scale fish culture activities. Most of them using a simple earthen pond. They did not apply any modern technique in culturing the fish. To improve the ability of the women community in culturing fish, a dissemination of environmental friendly fish culture technique was conducted. Slides and a simple manual book for conducting manipulated photoperiod in fish culture was used during the training. The community were also trained to construct tarp ponds, feeding, rearing Pangasius hypopthalmus and managing the water quality in the pond. Twenty five women that were belonged to "PKK" group attended the training. Before the training, their knowledge on fish culture was very low, but after the training, their knowledge improved by $85 \%$. Results of monitoring and evaluation activities shown that the women from the PKK group were able to culture fish with manipulated photoperiod technique.
\end{abstract}

Keywords: delima village; environmental friendly fish culture; manipulated photoperiod; tarp pond; cat fish culture

To cite this article: Windart., M. Riauwaty, H.y Syawal, A. H. Simarmata, \& I. Mulyani. 2019. Penyuluhan manipulasi fotoperiod pada budidaya ikan patin (Pangasius hypopthalmus) di RW VIII Kelurahan Delima Kecamatan Tampan Pekanbaru. Unri Conference Series: Community Engagement 1: 678-683 https://doi.org/10.31258/unricsce.1.678-683

(C) 2019 Authors

Peer-review under responsibility of the organizing committee of Seminar Nasional Pemberdayaan Masyarakat 2019 


\section{PENDAHULUAN}

Masyarakat Riau sangat menggemari ikan dan ikan merupakan salah satu sumberdaya yang memegang peranan penting dalam kehidupan masyarakat Riau. Berbagai jenis masakan khas Riau menggunakan ikan sebagai bahan utama, baik berupa ikan segar maupun ikan olahan seperti ikan asin dan ikan salai. Ikan juga memegang peranan penting dalam pelaksanaan adat di Riau, di mana di beberapa daerah dijumpai adanya ikan adat yang sering digunakan dalam upacara adat serta ikan-ikan yang pemanfaatannya diatur dengan kearifan lokal.

Masyarakat Riau terbiasa mengkonsumsi ikan-ikan liar yang ditangkap dari alam. Tetapi ikan-ikan yang hidup liar di sungai-sungai di Riau sudah semakin sedikit sehingga memicu masyarakat untuk melakukan budidaya ikan. Salah satu ikan yang banyak dibudidayakan oleh masyarakat adalah ikan patin. Ikan ini dibudidayakan baik dalam karamba, kolam maupun kolam terpal. Pemerintah juga mendorong masyarakat untuk melakukan usaha budidaya ikan. Upaya dari pemerintah ini diwujudkan dalam bentuk pemberian dukungan serta bantuan yang diperlukan untuk usaha budidaya ikan.

Salah satu daerah yang mempunyai potensi tinggi untuk dikembangkan adalah RW VIII, Kelurahan Delima, Kecamatan Tampan Pekanbaru. RW VIII merupakan salah satu wilayah di Kelurahan Delima dan areanya meliputi Perumahan Wadya Graha III dan wilayah Perumahan Ligako, dan terdiri dari 11 RT. Setiap RT terdiri dari sekitar 75 Kepala Keluarga. Di RW VIII ini kebanyakan ibu-ibu tidak bekerja, sehingga mereka mempunyai waktu luang dan berpotensi untuk dikembangkan.

Untuk memberdayakan ibu-ibu di RW VIII, kelompok ibu-ibu PKK di di bawah pimpinan ibu RW sering melakukan kegiatan. Kegiatan yang pernah dilakukan antara lain berupa pemeliharaan ikan lele dalam kolam terpal. Ibu-ibu memanfaatkan tanah fasilitas umum RW untuk membuat kolam terpal dan mengambil air dari sungai kecil yang ada di sana untuk irigasi kolam. Tetapi pada saat ini kegiatan pemeliharaan ikan tersebut tidak lagi dilakukan karena kesulitan modal. Oleh karena itu perlu adanya kegiatan pengabdian pada masyarakat tentang pemeliharaan ikan akan sangat bermanfaat.

Agar hasil budidaya ikan tinggi, diperlukan suatu upaya yang mudah, murah dan dapat dilakukan oleh semua orang, terutama ibu-ibu di RW VIII. Salah satu cara yang dapat dilakukan adalah dengan memanipulasi tingkah laku makan ikan. Windarti et al. (2013) menyatakan bahwa ikan selais yang dipelihara dalam suasana gelap terus menerus tumbuh lebih cepat daripada yang dipelihara pada fotoperiod natural. Ikan yang dipelihara dalam gelap menunjukkan tingkah laku yang lebih tenang dan responsif terhadap pakan yang diberikan (Windarti, 2016).

Ikan patin adalah ikan nokturnal yang aktif mencari makan pada waktu malam. Bila dipelihara di tempat gelap, diperkirakan ikan patin ini akan menjadi lebih tenang dan makan dengan lebih baik sehingga pertumbuhannya lebih cepat. Memelihara ikan dalam gelap ini juga murah serta mudah untuk dilakukan sehingga cocok untuk diterapkan untuk usaha budidaya ikan skala rumah tangga. Selain itu, upaya peningkatan efisiensi budidaya ikan patin ini juga dilakukan dengan pemberian herbal yang murah dan mudah didapat untuk meningkatkan daya tahan tubuh ikan, yaitu dengan pemberian kunyit sebagai campuran pakan ikan. Untuk mensosialisasikan teknik pemeliharaan ikan patin dalam gelap, maka perlu dilakukan "Penyuluhan Manipulasi Fotoperiod Pada Budidaya Ikan Patin di RW VIII Kelurahan Delima Kecamatan Tampan Pekanbaru”.

\section{METODE PENERAPAN}

Kegiatan pengabdian pada masyarakat ini akan dilakukan dengan cara penyuluhan. Dalam penyuluhan ini akan dilakukan beberapa tahap, yaitu:

\section{Ceramah tentang budidaya ikan patin dengan manipulasi fotoperiod}

Agar peserta penyuluhan dapat menyerap materi penyuluhan yang diberikan dengan baik, maka masingmasing peserta diberi buku TTG dan print out materi penyuluhan. Kemudian penyuluh menjelaskan tentang budidaya ikan patin dengan manipulasi fotoperiod dengan menggunakan slide yang dibuat dalam bentuk power point. Pada tahap ini penyuluh menjelaskan tentang cara-cara memelihara ikan patin yang benar dan cara memanipulasi fotoperiod. Penyuluh memperagakan cara membuat kolam terpal untuk pemeliharaan ikan yang ditutup dengan tenda plastik hitam untuk memanipulasi fotoperiod. Untuk patin, ikan dipelihara dalam kondisi gelap terus-menerus. Penyuluh juga memperagakan cara memberi makan ikan, merawat ikan serta menjaga kualitas air di kolam. 


\section{Diskusi dan evaluasi}

Pada sesi ini peserta diberi kesempatan untuk bertanya kepada penyuluh dan kemudian penyuluh akan menjelaskan/ menjawab pertanyaan tersebut. Kemudian penyuluh akan memberi pertanyaan kepada peserta untuk mengevaluasi daya serap mereka terhadap materi penyuluhan. Selain itu sikap antusiasme peserta selama jalannya penyuluhan dievaluasi dengan kriteria seperti tercantum pada Tabel 1. Selain itu peserta diberi pre test dan post tes. Kemudian hasil pre test dan post test dibandingkan.

Tabel 1. Kriteria antusiasme dan sikap peserta selama mengikuti penyuluhan

\begin{tabular}{lrl}
\hline \multicolumn{1}{c}{ Antusiasme peserta } & \multicolumn{1}{c}{ Skor } & \multicolumn{1}{c}{ Keterangan } \\
\hline Sangat rendah & $1,0-1,49$ & $\begin{array}{l}\text { Menunjukkan sikap ogah-ogahan dan meninggalkan ruangan } \\
\text { sebelum acara selesai } \\
\text { Menunjukkan sikap masa bodoh dan tidakmemperhatikan } \\
\text { materi yang disampaikan, tetapi tetap berada di ruangan } \\
\text { selama acara berlangsung }\end{array}$ \\
Rendah & $1,5-1,99$ & $\begin{array}{l}\text { Kadang-kadang memperhatikan, tetapi kadang-kadang } \\
\text { melakukan hal lain seperti asyik menggunakan HP } \\
\text { Sedang }\end{array}$ \\
Tinggi & $2,0-2,49-2,99$ & $\begin{array}{l}\text { Menyimak dengan baik, tetapi pasif, tidak aktif dalam } \\
\text { diskusi } \\
\text { Sangat tinggi }\end{array}$ \\
\hline
\end{tabular}

\section{HASIL DAN KETERCAPAIAN SASARAN}

\section{Kondisi umum RW VIII, Kelurahan Delima, Kecamatan Tampan Pekanbaru, Provinsi Riau}

Kelurahan Delima merupakan salah satu wilayah yang terletak di Kecamatan Tampan Pekanbaru. Wilayah RW VIII tersebut meliputi area Perumahan Wadya Graha III dan wilayah Perumahan Ligako, dan terdiri dari 11 RT. Di RW VIII terdapat area yang rendah di mana di area tersebut terdapat sungai kecil dan juga rawarawa yang berpotensi untuk digunakan sebagai sumber air pada usaha budidaya ikan.

Untuk memenuhi kebutuhan belanja bahan makanan sehari-hari, termasuk ikan, biasanya warga RW VIII berbelanja ke pasar Arengka atau ke kedai-kedai yang tersebar di mana-mana. Selain itu 2 kali seminggu juga ada pasar kaget yang menyediakan berbagai barang dan bahan makanan untuk keperluan rumah tangga. Ikanikan budidaya seperti ikan nila, ikan mas, gurami, lele dan lain-lain biasanya dijual dalam keadaan hidup. Karena ikan segar yang dijual di sekitar RW VIII harganya relative mahal, maka ibu-ibu di lingkungan RW VIII perlu diberi bekal pengetahuan untuk memelihara ikan yang mudah, murah dan dapat dilakukan oleh meraka. Bekal pengetahuan ini sangat penting bagi ibu-ibu di RW VIII tersebut, agar mereka dapat menyediakan selalu menyediakan ikan bagi keluarganya, atau bahkan menjual ikan hasil budidaya tersebut sebagai penghasilan tambahan.

Pada pelaksanaan berbagai kegiatan tersebut di atas, kendala besar yang menghambat jalannya kegiatan tidak ada. Kendala yang dijumpai antara lain hanya berupa sulitnya mencari waktu yang tepat untuk melaksanakan kegiatan. Tetapi hal ini bisa diatasi dengan adanya koordinasi yang baik antara mahasiswa/ dosen Pembina KKN dengan Ibu RW VIII. Secara umum masyarakat di RW VIII sera pihak Kelurahan sangat mendukung adanya kegiatan KKN tersebut.

Pada saat kegiatan sosialisasi budidaya ikan dengan manipulasi fotoperiod, ibu-ibu yang hadir pada pertemuan tersebut (sekitar 25 orang) sangat antusias dalam mengikuti ceramah. Karena beberapa orang ibu sudah mempunyai kolam, mereka mengajukan berbagai pertanyaan yang berkaitan dengan pemeliharaan ikan di kolam. Mereka juga menunjukkan minat yang besar untuk memelihara ikan dengan manipulasi fotoperiod.

\section{Pelaksanaan penyuluhan budidaya ikan patin dengan manipulasi fotoperiod}

Penyuluhan tentang Budidaya ikan patin dengan Manipulasi Fotoperiod dilakukan pada bulan Juni - Juli 2019. Kegiatan penyuluhan ini dilaksanakan di gedung Pendopo RW VIII Desa Delima. Acara ini dihadiri oleh 25 orang peserta, semuanya adalah ibu-ibu yang tergabung dalam Kelompok PKK RW VIII. Ibu-ibu yang datang pada acara ini memiliki berbagai latar belakang pendidikan serta bidang usaha, tetapi sebagian besar 
merupakan ibu rumah tangga. Ada beberapa orang yang sudah pernah melakukan usaha budidaya ikan di kolam tetapi kemudian tidak aktif lagi karena berbagai kendala yang dijumpai.

Ibu-ibu di RW VIII menyambut baik adanya kegiatan ini. Hal ini terlihat dari antusiasme mereka dalam menyambut acara ini dan mereka sudah datang pendopo sebelum acara dimulai. Kebanyakan dari ibu-ibu tersebut ingin mendapatkan bekal pengetahuan tentang cara memelihara ikan yang efektif, murah dan mudah untuk dilakukan. Penyuluhan dilakukan dengan cara menayangkan slide yang sudah dipersiapkan dan penjelasan secara sederhana tentang upaya pemeliharaan atau budidaya ikan lele dumbo dengan metode manipulasi fotoperiod. Selain itu pesert penyuluhan juga diberi buku TTG tentang budidaya ikan dengan manipulasi fotoperiod.

Tim penyuluh memperagakan cara membuat instalasi wadah budidaya ikan dengan manipulasi fotoperiod. Peragaan ini meliputi penjelasan tentang membuat kolam terpal dan tenda untuk menghalangi sinar matahari serta merancang sirkulasi air agar ikan dapat tumbuh baik selama proses budidaya. Selama jalannya penyuluhan ibu-ibu menyimak dengan baik.

Setelah dijelaskan, peserta diberi kesempatan untuk bertanya atau melakukan diskusi dengan tim penyuluh. Kebanyakan pertanyaan diajukan untuk mengetahui tentang cara budidaya berbagai jenis ikan, keterbatasan air, cara memberi makan serta cara merawat ikan bila terserang penyakit.

Hasil pengamatan terhadap sikap antusiasme peserta penyuluhan menunjukkan bahwa hampir semua peserta menunjukkan antusiasme tinggi atau sangat tinggi. Hanya 1 orang yang menunjukkan antusiasme sedang (Tabel 2). Rerata skor antusiasme peserta adalah 34,1 atau berkisar antara antusias tinggi dan sangat tinggi. Hal ini menunjukkan bahwa kebanyakan dari masyarakat tersebut ingin mendapatkan bekal pengetahuan tentang pemeliharaan ikan dengan manipulasi fotoperiod, agar dapat melakukan usaha tersebut dengan baik.

Tabel 2. Hasil evaluasi sikap antusiasme peserta selama mengikuti penyuluhan

\begin{tabular}{lccc}
\hline \multicolumn{1}{c}{ Antusiasme peserta } & Skor & Jumlah & Total skor \\
\hline Sangat rendah & 1 & 0 & 0 \\
Rendah & 2 & 0 & 0 \\
Sedang & 3 & 3 & 9 \\
Tinggi & 4 & 14 & 56 \\
Sangat tinggi & 5 & 8 & 40 \\
\hline & & Total & 105 \\
\hline
\end{tabular}

Pada saat pelaksanaan penyuluhan, peserta diberi pre test dan post test untuk mengetahui pemahaman mereka tentang budidaya ikan dengan manipulasi fotoperiod. Pre test diberikan untuk mengetahui seberapa jauh pengetahuan mereka tentang budidaya ikan patin, tentang manipulasi fotoperiod dan tentang pengelolaan kualitas air. Adapun hasil pretest dan posttest dapat dilihat pada Tabel 3 dan Gambar 1 di bawah ini:

Tabel 3. Hasil pretest dan posttest

\begin{tabular}{clcc}
\hline No & \multicolumn{1}{c}{ Topik } & Rerata nilai pre test & Rerata nilai post test \\
\hline 1 & $\begin{array}{l}\text { Pemahaman tentang budidaya ikan secara } \\
\text { umum }\end{array}$ & 65 & 86 \\
2 & $\begin{array}{l}\text { Pemahaman tentang budidaya ikan patin } \\
3\end{array}$ & 60 & 82 \\
$\begin{array}{l}\text { Pemahaman tentang manipulasi } \\
\text { fotoperiod }\end{array}$ & 40 & 75 \\
4 & $\begin{array}{l}\text { Pemahaman tentang perawatan/ } \\
\text { pemeliharaan ikan }\end{array}$ & 70 & 85 \\
5 & $\begin{array}{l}\text { Pemahaman tentang pengelolaan kualitas } \\
\text { air di kolam }\end{array}$ & 60 & 84 \\
\hline & Rerata & 59 & 82,4 \\
\hline
\end{tabular}




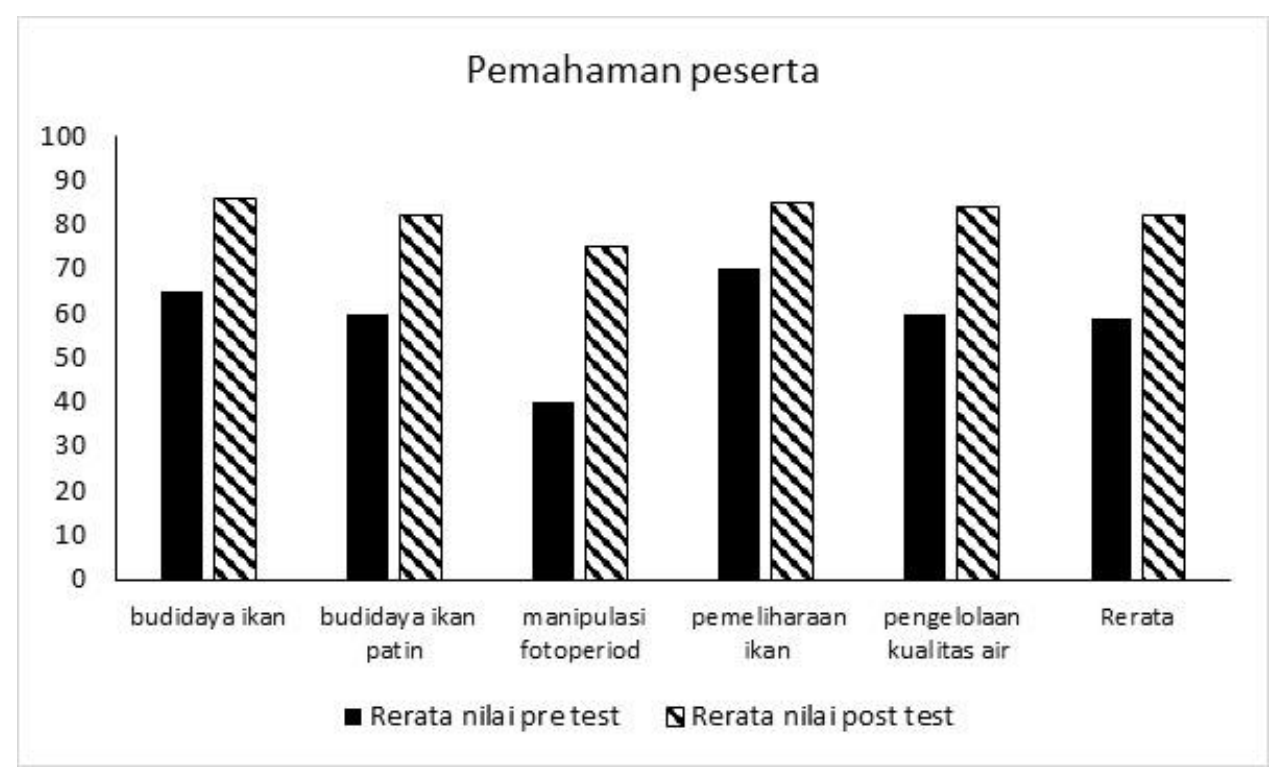

Gambar 1. Hasil pretest dan posttest

Dari Tabel 3 dan Gambar 1 dapat dilihat bahwa nilai pemahaman peserta terhadap materi penyuluhan mengalami peningkatan. Hasil pretest menunjukkan bahwa pengetahuan peserta terhadap budidaya ikan patin dengan manipulasi fotoperiod masih rendah. Setelah mengikuti penyuluhan, pemahaman mereka meningkat dan hal ini ditunjukkan dengan adanya peningkatan nilai menjadi 82,4. Hal ini menunjukkan bahwa materi penyuluhan tersebut dapat dipahami oleh ibu-ibu dari RW VIII Kelurahan Delima. Hal ini sesuai dengan pendapat Yuhanna dan Yulistiana (2017) yang menyatakan bahwa penyuluhan bermanffat untuk meningkatkan pengetahuan dan ketrampilan masyarakat. Dengan meningkatnya pengetahuan masyarakat tentang budidaya ikan ini diharapkan agar nantinya masyarakat dapat mengembangkan usaha budidaya ikan untuk meningkatkan taraf ekonomi mereka. Hal ini sesuai dengan pendapat Hudaidah et al., (2017) dan Darmansyah et al., (2016) yang menyatakan bahwa usaha budidaya ikan dapat meningkatkan taraf hidup masyarakat.

\section{KESIMPULAN}

Dengan adanya penyuluhan ini dapat disimpulkan bahwa masyarakat RW VIII Kelurahan Delima belum mempunyai bekal pengetahuan yang cukup di bidang pemeliharaan ikan patin dengan manipulasi fotoperiod. Selama ini upaya budidaya ikan masih dilakukan secara konvensional. Adanya penyuluhan ini sangat bermanfaat dalam memberikan bekal ilmu pengetahuan sehingga petani ikan mengetahui cara memelihara ikan patin secara efektif,murah dan mudah dilakukan dengan manipulasi fotoperiod .

\section{UCAPAN TERIMA KASIH}

Ucapan terimakasih kami sampaikan kepada Universitas Riau yang telah memberikan dana untuk pelaksanaan kegiatan pengabdian pada masyarakat yang tergabung dengan kegiatan KKN Terintegrasi. Terimakasih juga kami sampaikan kepada warga, serta Ketua RW VIII dan Kepala Desa Delima Kecamatan Tampan Pekanbaru yang mendukung jalnnya kegiatan KKN Terintegrasi ini. Semoga apa yang kami lakukan di Kelurahan Delima dapat bermanfaat untuk kita semua.

\section{DAFTAR PUSTAKA}

Darmansyah, A. Sulistiono, Nugroho, \& Supriyono. 2016. Pemberdayaan masyarakat melalui pengembangan budidaya ikan lele di Desa Balongan Indramayu, Jawa Barat. Agrokreativ Jurnal Ilmiah Pengabdian Kepada Masyarakat, $2(1), 8-16$.

Hudaidah, S., Wardianto, Q. Hasani, \&M.W. Yusup. 2017. Pemberdayaan masyarakat melalui pengembangan budidaya ikan lele dengan teknik budidaya bioflok di Kelurahan Pinang Jaya Bandar Lampung. Jurnal Pengabdian Kepada Masyarakat Sakai Sembayan, 6 hlm 
Windarti, B. Heltonika, \& Sukendi. 2013. Pemenuhan kebutuhan energi ikan selais (Ompok hypopthalmus) berkaitan dengan aktivitas reproduksi. Laporan Penelitian. Lembaga Penelitian Universitas Riau. Tidak diterbitkan.

Windarti., \& B. Heltonika. 2016. Manipulasi fotoperiod untuk memicu pematangan gonad pada ikan selais (Ompok hypopthalmus). Laporan Penelitian. Lembaga Penelitian Universitas Riau. Tidak diterbitkan

Yuhanna, W.L., \& Y.G. Yulistiana . 2017. Pemberdayaan masyarakat Desa Wakah, Kecamatan Ngerambe melalui pembuatan pakan lele alternative dari ampas tahu dan probiotik. Agrokreativ Jurnal Ilmiah Pengabdian Kepada Masyarakat, 3(2), 108-114. 